\title{
Industrial sector engineering staff development systems
}

\author{
Galina Armashova-Telnik ${ }^{1, *}$, Anna Zubkova ${ }^{1}$, Alexandra Melnichenko ${ }^{1}$, Veronika \\ Semenova ${ }^{1}$, Polina Sokolova $^{1}$, and Yulia Terentyeva ${ }^{1}$ \\ ${ }^{1}$ Saint-Petersburg State University of Aerospace Instrumentation, 190000, Bolshaya Morskaia str., 67, \\ Saint-Petersburg, Russia
}

\begin{abstract}
This article discusses methods for the employees quality and performance improvement in the electric power industry enterprises. The characteristics of the factors influencing the development of personnel are given. The foreign experience of corporate training is analyzed, which identifies ways to improve labor activity, maintain labor discipline, increase the level of labor motivation, develop corporate culture and increase the employee loyalty at industrial enterprises. The structure of personnel training methods at the enterprise is schematically presented. The article substantiates the need for the formation of a qualified human resource that provides the company with the growth of economic indicators of production activity, a high degree of competitiveness in the industry market, and a positive image of the organization
\end{abstract}

\section{Introduction}

Focusing on the need for new domestic technologies development, economic and industrial growth, it is necessary to concentrate on the most important fields of the global industry, in which the global technological competitiveness of Russia can highly likely be ensured.

It takes colossal financial investments and an efficient labour management system to create highly intelligent human resources capacity and jobs in the energy sector of Russia.

The relevance of this study is conditioned by the high dynamic changes in industrial enterprises caused by the aging of the regular labour force. The pace of economic, technological and cultural transformation in modern enterprises is very high and tends to constant acceleration. Consequently, the greatest demand in modern society is received by specialists who can quickly adapt to the changes taking place in society, and who have the necessary qualities for this. [1]

Enterprises in the industrial sector are also subject to the changes taking place in modern society and require specially trained people who can work and make effective decisions in a rapidly changing environment. That is, one of the key tasks in the development of engineering personnel in the industrial sector is to solve problems in the training and development of personnel.

It should be noted that the stages of employee training represent one of the main "sore

\footnotetext{
*Corresponding author: atgs@yandex.ru
} 
spots" of staff development at the industrial enterprises. Since personnel training is a very multifaceted process, which includes many stages (from school to universities), it is advisable to consider it in terms of the active integration of business into education. This will allow to neutralize the severity of the staff shortage problem by involving the educational institutions, including supplementary vocational education in the process of mobile response to the demands of the real sector of the economy, which in turn creates the demand for educational services of supplementary vocational education organizations [3].

In addition, in a number of industrial sectors in Russia, structural modernization and reorganization has been implemented at all the performance levels of the industry. Thus, a large-scale reform of the Russian energy sector has set serious tasks for the industry, having expanded grandiose energy construction projects throughout the country. The reformers did not take into account one thing in these plans - the staff component $[4,5]$. Thus, the staff turnover in the electrical energy industry has become one of the main problems of the industry (tab. 1). The electrical energy industry, like many other industrial sectors, is facing the trend of aging personnel [6]. There are practically no middle-aged specialists at the enterprises. With the aim of rejuvenating the personnel, layoffs of retired workers with rich professional experience have become more frequent, and as a result, there is no one to teach young people who come.

Table 1. Work experience of employees in the electrical energy industry (according to https://rosstat.gov.ru/).

\begin{tabular}{|l|c|c|c|c|c|c|}
\hline \multicolumn{1}{|c|}{$\begin{array}{c}\text { Work } \\
\text { experience }\end{array}$} & \multicolumn{7}{|c|}{ The number of employees (\%) } \\
\cline { 2 - 7 } & $\mathbf{2 0 1 3}$ & $\mathbf{2 0 1 4}$ & $\mathbf{2 0 1 5}$ & $\mathbf{2 0 1 6}$ & $\mathbf{2 0 1 7}$ & $\mathbf{2 0 1 9}$ \\
\hline $\begin{array}{l}\text { Less than one } \\
\text { year }\end{array}$ & 2 & 1 & 1 & 2 & 2 & 1 \\
\hline $\begin{array}{l}\text { One - three } \\
\text { years }\end{array}$ & 7 & 4 & 4 & 5 & 6 & 4 \\
\hline $\begin{array}{l}\text { Three - five } \\
\text { years }\end{array}$ & 16 & 15.2 & 15 & 12 & 12 & 9 \\
\hline Five -ten years & 19 & 17 & 14 & 16 & 16 & 21 \\
\hline $\begin{array}{l}\text { Ten - twenty } \\
\text { years than }\end{array}$ & 37 & 35 & 38 & 38 & 38 & 40 \\
\hline $\begin{array}{l}\text { More } \\
\text { twenty years }\end{array}$ & 18 & 18 & 20 & 20 & 23 & 25 \\
\hline
\end{tabular}

In addition, there is an active decline in the age statistics of middle-aged specialists at industrial enterprises (table 2) [8].

Table 2. Average age of employees of industrial enterprises (according to https://rosstat.gov.ru/).

\begin{tabular}{|c|c|}
\hline & Average age of employees (years) \\
\hline 2009 & 43.9 \\
\hline 2010 & 42.5 \\
\hline 2011 & 42.9 \\
\hline 2012 & 43.0 \\
\hline 2013 & 43.0 \\
\hline 2014 & 43.5 \\
\hline 2015 & 46.3 \\
\hline 2016 & 42.7 \\
\hline 2017 & 44.2 \\
\hline 2018 & 47.3 \\
\hline 2019 & 47.5 \\
\hline
\end{tabular}


Table 3. The number of retired workers of an industrial enterprise (according to https://rosstat.gov.ru/).

\begin{tabular}{|c|c|c|}
\hline & $\begin{array}{c}\text { The number of employees who resigned } \\
\text { voluntarily (in\% of the total number of } \\
\text { employees who left) }\end{array}$ & $\begin{array}{c}\text { The number of employees } \\
\text { who got laid off due to } \\
\text { downsizing (in\% of the total } \\
\text { number of employees who } \\
\text { left) }\end{array}$ \\
\hline 2009 & 58.6 & 7.6 \\
\hline 2010 & 60.0 & 5.8 \\
\hline 2011 & 58.6 & 6.0 \\
\hline 2012 & 64.9 & 4.1 \\
\hline 2013 & 61.0 & 4.3 \\
\hline 2014 & 57.9 & 5.5 \\
\hline 2015 & 54.2 & 6.2 \\
\hline 2016 & & \\
\hline 2017 & 55.9 & 4.6 \\
\hline 2018 & 56.9 & 3.7 \\
\hline 2019 & & \\
\hline
\end{tabular}

Thus, half of industrial companies are now experiencing a shortage of production and engineering staff. Experts share one view that the degradation in the staffing situation is conditioned by the fact that companies recklessly dismissed too many specialists during the period of unfavourable volume variance. And when the volumes began to recover, the enterprises could not promptly attract the required number of workers $[10,15]$.

As a result, a paradoxical situation began to unfold when employers are trying to detain older workers. The natural loss of the experienced personnel is extremely difficult to compensate for.

Today, the average age of workers in a large number of enterprises, especially in the defense-industrial sector, is close to the retirement age. Although the situation is gradually changing for the better.

According to Tables 2 and 3, the analysis of the current situation allows to conclude that the problem of staffing in production and the demand for the trained personnel will hold relevance for a long time.

The total number of corporate staff in the industry is about 290 thousand people. The average age of workers in the industry is 45-50 years. At the same time, a low proportion of middle-aged specialists is characteristic. The dynamics of the total number of employees in the industry is characterized by stable growth. The average headcount of staff in 2018 exceeded the 2008 value by 6.6 percent. The share of scientific personnel is growing. The organizations employees remuneration rate in the industry from 2008 to 2018 increased 2.9 times. A serious personnel problem in the industry is the incomplete correspondence of the workers' professional competencies with the desirable qualifications $[10,11]$.

\section{Materials}

Let's emphasize that within the solving the "sore spot" with staffing, a significant proportion of Russian enterprises are guided by the idea that the training received at the university is not enough for the employee to start a successful professional activities, since higher education is only the initial stage in the competent employee development [12 ]. Thus, the essential significance of the effective performance of the company currently falls on the creation of such labor activity conditions under which the growth of the employees professional and personal competencies level is possible with the help of the staff training and development system [15]. 
At the same time, it is necessary to focus on the significance of factors affecting the growth of the priority of employee development (Fig. 1)

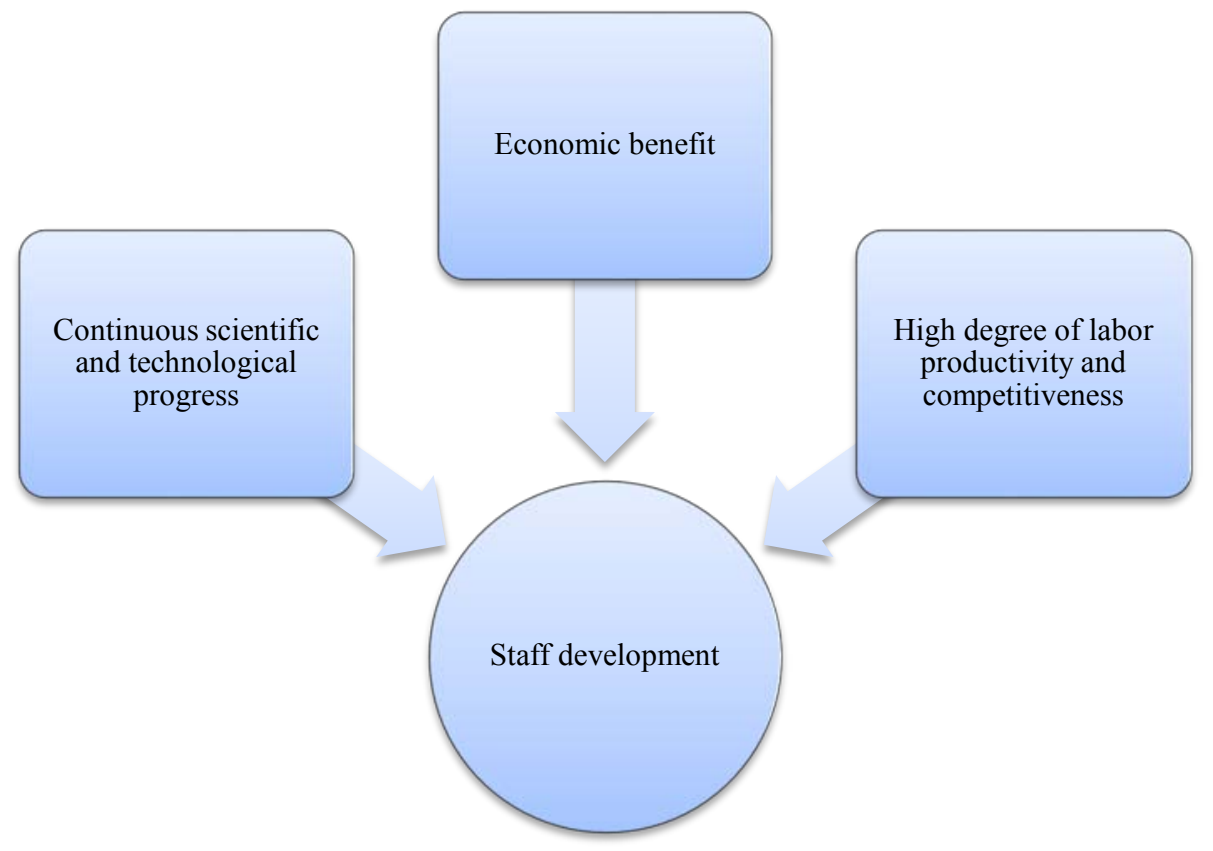

Fig. 1. Factors influencing staff development.

From the data in Figure 1, it follows that the desire to develop the enterprise staff composition is influenced by such factors as continuous scientific and technological progress within the country and in the world, since this determines the introduction of new technologies into production.

Staff training plays the significant role for most Russian enterprises. This is determined by the growing market requirements for a qualitatively new personnel skill level. Yesterday's knowledge, attitudes and skills that help staff to work successfully are losing their relevance today. Rapidly changing external (legislation, taxation system, new competitors, economic and political strategy of the state) and internal (changes in production technologies, corporate restructuring, reduction or appearance of created jobs) conditions of the organization's functioning justify the need for staff training. The economic benefit for the enterprise obtained after training employees and high labor productivity and competition among enterprises in this industry. The essential significance of the company's effective performance currently falls on the growth of the employees' professional and personal expertise level through the system of staff training and development. The economic benefit for the organization, continuous scientific and technological progress, a high degree of labor productivity and staff competitiveness are factors influencing the staff development priority growth [19,22].

In general, there is a tendency in Russia to increase the expenditures on the educational function of the employees' development in the electrical energy industry. For example, as a result of a study by the «Head Hunter Salary Databank» in 2019, interviewing 521 representatives of Russian energy companies, it was revealed that a quarter of the respondents plan to increase the cost of training their staff. This is due to the achievement of certain goals (Fig. 2). 


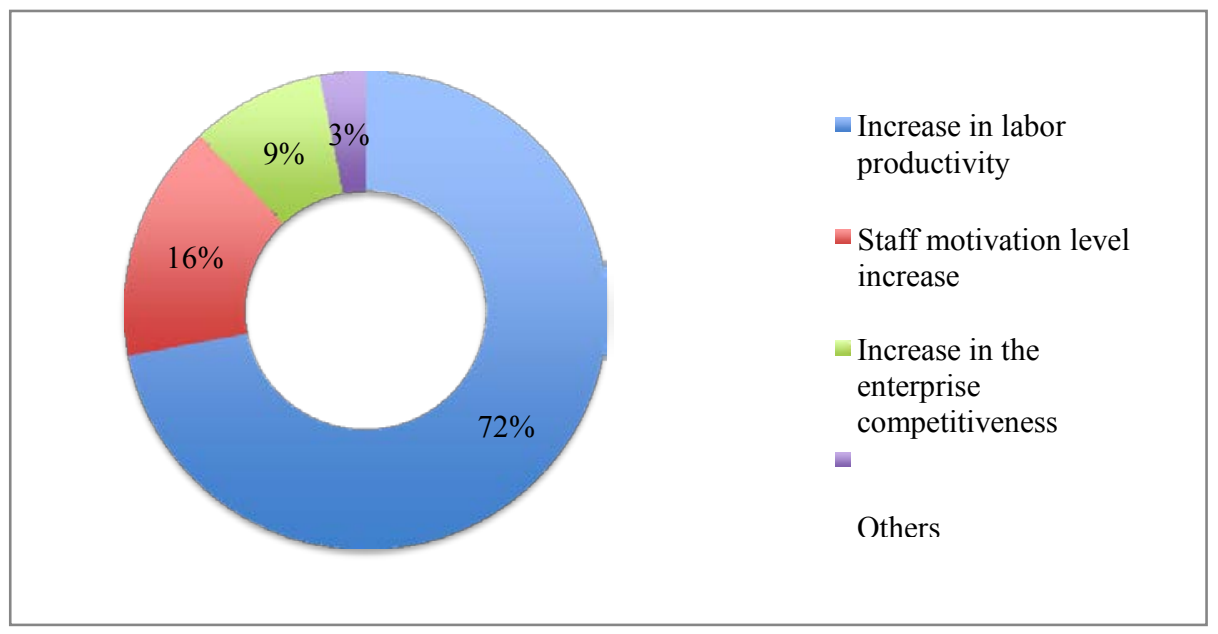

Fig. 2. Training objectives.

Based on these diagrams, it can be concluded that the most common goal of staff training among respondents is to increase the labor productivity $(72 \%)$, the second place belongs to the staff motivation increase (16\%), the third place is taken by the increase in the enterprise competitiveness (9\%) [24]. The modern labor market places demands on the staff training improvement in all branches of production. Thus, the trained staff becomes an important factor in the stable enterprise activity. According to Rosstat, the need for retraining and advanced training increases significantly in a number of industrial sectors. The percentage of enterprises interested in training their employees in production is growing every year, regardless of the industry [25].

Let's consider the data on the enterprises of the electrical energy industry (Fig. 3).

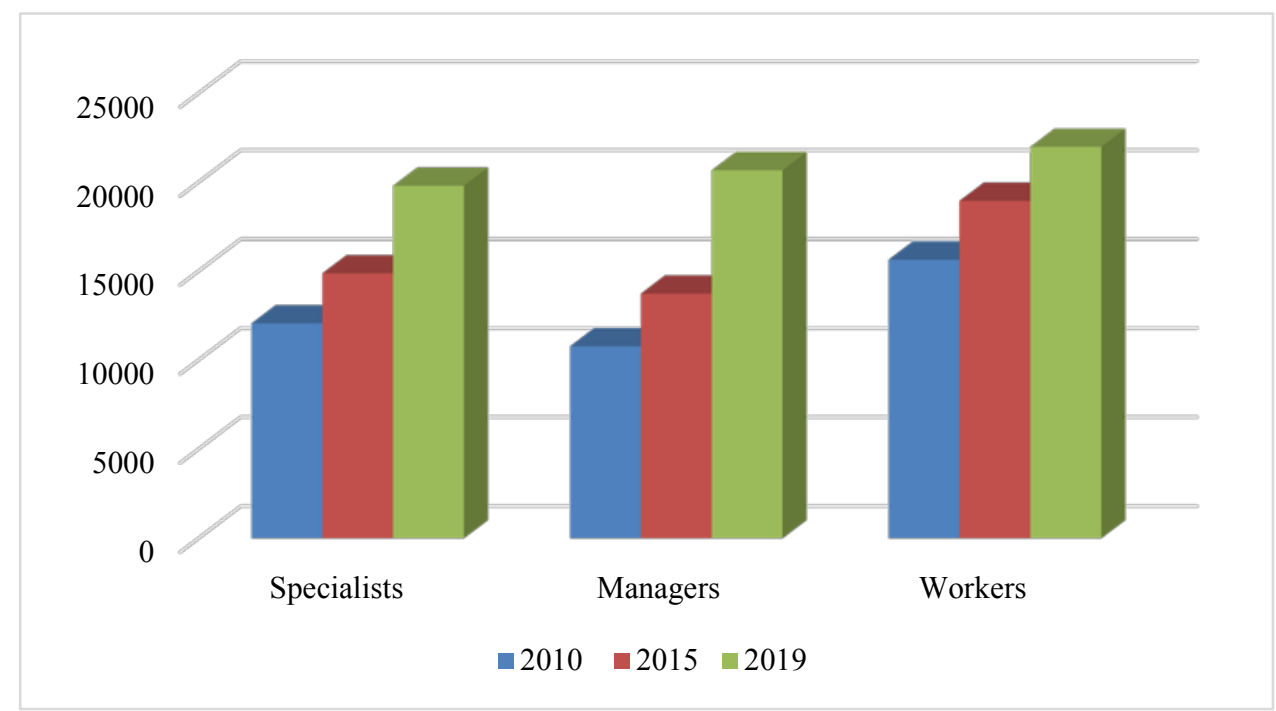

Fig. 3. Staff training expenses (thousand rubles) from 2010 to 2019.

Figure 3 shows the specialists, managers, workers training expenses for the period 2010-2019. It is obvious that the staff training expenses are growing every year, this is determined by the growing interest in high-skilled workers and legislative requirements for 
the staff of electrical energy industry.

It should be noted that significant experience of corporate training implementation has been accumulated in countries such as the USA, UK, France and Japan. Thus, the United States can rightfully be called the country of corporate training origin in the form in which we used to see it in modern Western companies. It was in this country that the first corporate university called Gamburger University appeared at McDonalds in 1961. Corporate training in the United States is focused on the further development of the university graduates and, first of all, the management staff. The probability to complete the curriculum of corporate training programs is $50 \%$ higher for the staff with higher education. At the same time, among the managers with Masters or PhD degrees the chances to be internally trained are twice as much as among those with Bachelor degrees. Americans consider that a small, skilled management staff is the key to increase the company's profitability. Corporate training in the USA finds its implementation mainly in large companies, as it requires large investments from organizations. Nevertheless, other practices are also widespread, when enterprises, without their own corporate training systems, unite and create inter-company training centers for internal staff training. This is an undeniably effective approach, since it allows the employees of enterprises in the same market segment to exchange experience and solve business cases that are applicable in practice, as well as minimize training costs without losing quality. Unlike the Japanese and German companies in the United States, staff training is not considered as a part of organizations' competitive strategy. The total amount of annual expenditures on corporate training per capita in the United States is two times less than, for example, in German companies, and 17 times less when training workers. While in France the companies receive tax incentives from instilling of corporate training culture in their employees, in the United States, the government establishes flexible policies and strategic recommendations to support staff development, but does not participate in the management of staff knowledge management strategies [29]. It is important to note that practice in the application of a project-based approach to corporate education is currently emerging in the United States. Namely, the creation of a combined variant of the corporate universities based on the interaction of business and education [33].

In France, corporate training is usually provided through short-term and highly specialized courses. The system is based on staff training and retraining, taking into account the specifics of the business sectors in which the company currently operates. The systems of corporate staff retraining and competence development consist of training tasks and goals related to the the company's general strategy and are divided into components:

1) department managers training;

2) practical training of employees and carrying out an operational (periodic) assessment of the material mastering results.

There is a balance between the training duration and the target audience (different industries) of the staff. French researchers note that annually $30 \%$ or more specialists from each industry in production must improve their knowledge and skills.

UK companies prefer to train and develop their employees in the workplace because external learning is sometimes problematic. That's why the management staff has to put up with the fact that workers are absent from workplace and plan their off-hours with the training program period. And the last but not least, the external training for employees in this country is considered expensive. The significant disadvantage is that the knowledge gained during the external training course often does not correspond to the current standards and established requirements of the company [41]. In the UK companies on-thejob training is one of the most effective and cost-effective ways to develop staff competence. Among the various popular teaching methods, the two most cost efficient and well-proven teaching methods are advanced experience (exchange of know-how) and 
mentoring. Despite the profitability of British companies, the actual costs of corporate training account for $3 \%$ of the total labor costs of the wage and salaries fund, which is $2.7 \%$ more than in the largest organizations in Russia [42].

In Japan, in return, corporate training has become widespread as the most effective and cost-effective ways to develop staff competence. It is based on the practice of lifelong recruitment, on-the-job training, staff turnover, seniority supplement increases, and the reputation system. Companies hire university graduates, young staff undergoes the corporate training and stays on for almost entire live. There is a practice of moving employees every 2-3 years along the horizontal and vertical corporate ladder (staff turnover), often without the consent of the employee himself. This approach allows the employee to expand the detailed understanding of the organization's business. It is quite difficult for subordinates to deceive the manager with such knowledge of the details of the working process, and, of course, such qualifications help to reduce the probability of unprofessional decision-making. In addition, the Japanese model of corporate training includes training outside working hours. The mentoring institution is highly developed, based on the respect and reputation of employees (often of the older generation), and not on the professional indicators of the employee (in contrast to the UK). The core principle of one of the leading Japanese companies, Toyota, as Jeffrey Liker, professor of industrial and operational engineering at the University of Michigan states in his research, is becoming an organization with the help of the learning structure through the incessant introspection and continuous improvement. It is no coincidence that this principle tops the pyramid of the «Dao Toyota», since the creation of a learning structure represents the highest organization efficiency level. The main responsibility of any manager at Toyota is to train people [43], which directly contradicts the American mentality of building the corporate training, where the employee or corporate training centers are responsible for developing skills.

As for the Russian companies, the corporate training is represented here by different models depending on the size of the organization: Department of Education, Training Center or Corporate University [44]. The experience gained in the framework of foreign corporate training, as well as the study of the advantages and disadvantages associated with the applied methods, allows to work out and develop the educational process, taking into account its potential for successful application in the Russian corporate education system. In the management of corporate training and staff development, the variety of techniques and methods are used, such as: modular training, case training, practical course, coaching, business game, role-playing game, metaphorical game, "brainstorming", project method ("project design training"), behavioral modeling, mentoring, storytelling, training of a work team, in-basket training, rotation through the ranks (horizontal, vertical) and others. One of the most important tasks of the corporate training management is to adapt educational techniques, methods and ways of teaching to specific requirements. For example, the international best practices related to the training of corporate HR specialists (including corporate trainers) are used "carefully" in Russia, because most enterprises and companies remain closed to innovations in the field of staff training and staff competencies or expertise development. At the same time, the rational organization of corporate training contributes to the profitability of the enterprise, and its employer becomes prestigious in the job seekers' sight, contributes to the enterprise internal culture development, the improvement of mentoring and has a positive effect on the enterprise competitiveness as a whole. Simple copying the foreign forms and methods of training the corporate HR specialists is an unreasonable and unprofitable way. It is necessary to conduct a constructive analysis of their use in the conditions of the Russian enterprises [41, 45]. Otherwise, we may lose the opportunity to develop domestic practices in the field of engineering pedagogy, which should serve as a guideline and ensure the progressive development of corporate training for leading Russian companies. 


\section{Results}

As a result of the foreign and domestic corporate training experiences analysis, it is possible to construct a scheme of staff training methods, illustrating the complexity and interrelation of these methods when effective introduction of staff training at the enterprise. (Fig. 4)

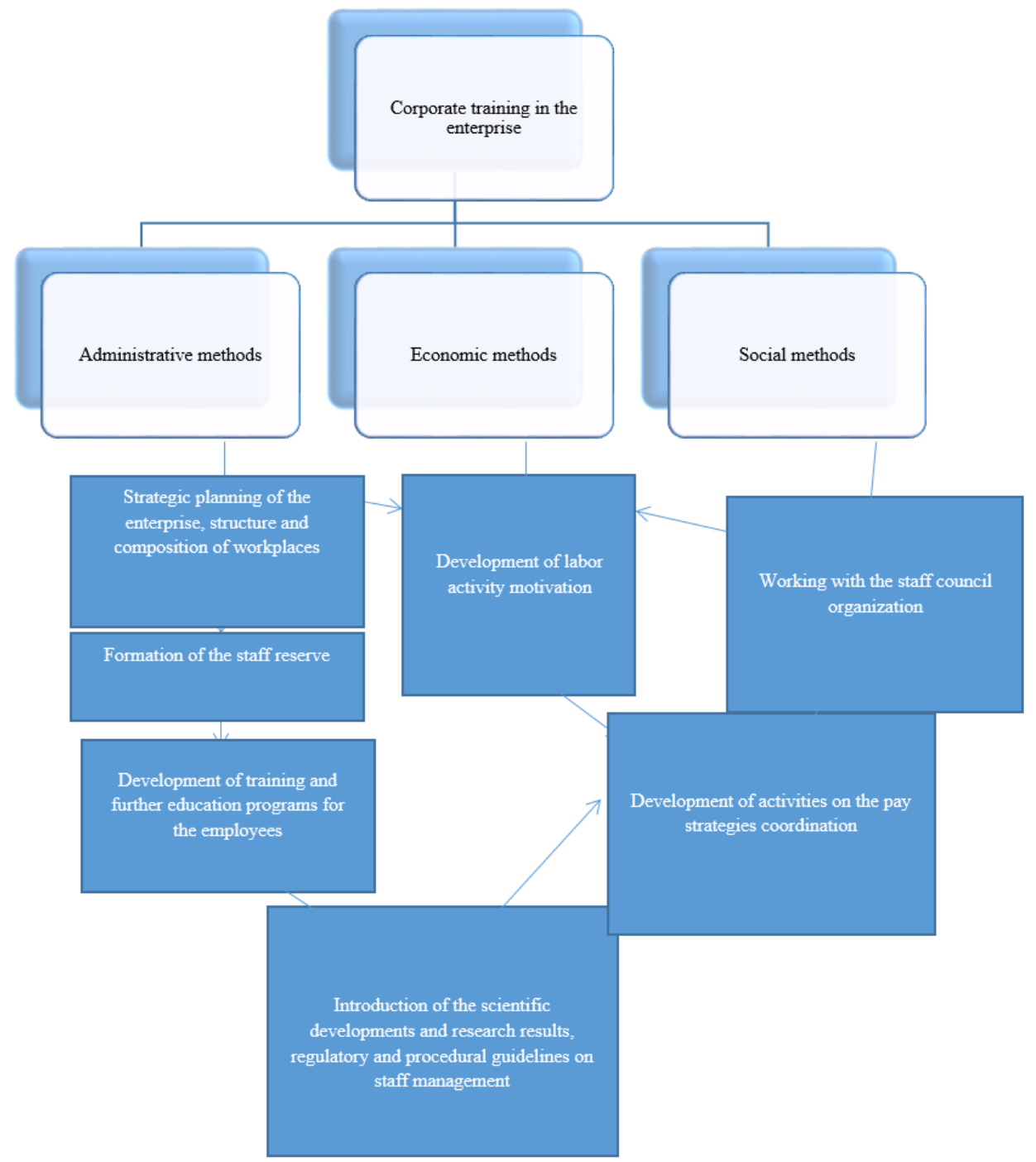

Fig. 4. Scheme of staff training methods at the enterprise.

\section{Conclusion}

Thus, all of the above methods, which are popular in foreign practice of corporate training, allow to conclude that the crucial significance to transfer or offering the strong and vast experience is a balanced, integral and effective set of methods that ensure the competitive capacity of an organization. The analysis of international experience in the field of staff training and development management has shown that, like any other management process, this method of management implies the need for a systematic approach and careful 
planning. The first place in forming up the training system is to determine the needs of an organization in this field. In this regard, it is necessary to identify the compliance of staff's professional knowledge, skills and expertise with the strategic goals of the company. The choice of the appropriate corporate training method depends on the specifics of the fields and business, as well as the country's development level. In conclusion, it should be noted that the experience gained in foreign and Russian corporate training, as well as an analysis of the advantages and disadvantages of internal training implementation methods in various countries, allow to design and develop the training process, taking into account its potential for successful application in the Russian corporate education system. This experience is useful in the development of special methods and techniques, training programs, training and teaching materials at Russian enterprises.

\section{References}

1. Russian statistical annual book. 2019: Statistical collection (Rosstat., M., 2019)

2. Russia in numbers. 2020: Statistical collection (Rosstat., M., 2020)

3. Proceedings of 2018 17th Russian Scientific and Practical Conference on Planning and Teaching Engineering Staff for the Industrial and Economic Complex of the Region PTES 20187 (2019)

4. Heywood, J., ASEE Annual Conference and Exposition, Conference Proceedings (2014)

5. Okafor, U.C., Worlu, R.E., Obi, J.N.,et al, Journal of Physics: Conference Series 1378(2) (2019)

6. Loper, M.L., Bronston, M., Berenbach, B., Simulation in Systems Engineering: A Survey Course Proceedings - Winter Simulation Conference 9004797, 3295-3306 (2019)

7. Noguez, J., Neri, L., International Journal on Interactive Design and Manufacturing 13(4), 1283-1295 (2019)

8. Ure, O.B., Skauge, T., International Journal for Research in Vocational Education and Training 6(3), 203-223 (2019)

9. Huilier, D.G.F., Fluids 4(4), 199 (2019)

10. Ilme, Y., Can, E., Ozay, M.E., AIP Conference Proceedings 2178, 030060 (2019)_

11. Wilson, C., Hirtz, M., Levkin, P.A., Sutlief, A.L., Holmes, A.E., Journal of Chemical Education 96(11), 2441-2449 (2019)

12. O. Lebedev, Mokeeva, T., Alamshoev, A., ACM International Conference Proceeding Series 3373327 (2019)

13. O.O. Gorshkova, International Journal of Engineering and Advanced Technology 9(1), 3881-3887 (2019)

14. G.A. Mousa, Elamir, E.A.H., International Conference on Innovation and Intelligence for Informatics, Computing, and Technologies, 3ICT 8910288 (2019)

15. Á.H. Galvis, Avalo, A., Ramírez, A., Cortés, D.C., Cantor, H., Reengineering engineering education at the University of los Andes: The REDINGE2 pilot project Kybernetes 48(7), 1478-1499 (2019)

16. J. Maguire, Sheridan, N., Draper, S., Cutts, Q., ICER 2019 - Proceedings of the 2019 ACM Conference on International Computing Education Research (2019)

17. T. Kohler, Wollersheim, H.-W., Igel, C., Proceedings - 2019 8th International Congress on Advanced Applied Informatics, IIAI-AAI 8992686, 240-245 (2019) 
18. T.N. Korneenko, Kravchenko, O.V., Deinekina, N.A., IOP Conference Series: Earth and Environmental Science 272(3), 32135 (2019)

19. I. Hilliger, Celis, S., Pérez-Sanagustín, M., Baier, J., ASEE Annual Conference and Exposition, Conference Proceedings (2019)

20. F. Schmidt, Schmitt, F.-J., Böger, L., Wilhelm-Weidner, A., Torjus, N., ASEE Annual Conference and Exposition, Conference Proceedings (2019)

21. M. Magnell, , Geschwind, L., Higher Education Research and Development 38(4), 807-818 (2019)

22. A. Minina, Mabrouk, K., Proceedings of the 2019 IEEE Communication Strategies in Digital Society Seminar, ComSDS 8709652, 117-120 (2019)

23. N. Casalino, Borin, B., Pizzolo, G., Cavallini, S., IEEE Global Engineering Education Conference, EDUCON 8725229, 1534-1541 (2019)

24. S. Ahuja, S. Gupta, International Journal of Recent Technology and Engineering 7(6), 1846-1851 (2019)

25. A. Cerezo-Narváez, de los Ríos Carmenado, I., et al., Education Sciences 9(1), 44 (2019)

26. J.M. Antony Raj, Ashok, J., Murugappan, S., Indian Journal of Public Health Research and Development 10(3), 1066-1071 (2019)

27. H. Kalawilapathirage, Omisakin, O., Zeidan, S., Journal of Information and Knowledge Management 18(1), 1950003 (2019)

28. G.A. Mousa, Elamir, E.A.H., International Conference on Innovation and Intelligence for Informatics, Computing, and Technologies 3ICT 8910288 (2019)

29. V.N. Kruglikov, Obrazovanie i Nauka 20(6), 50-69 (2018)

30. S.R. Mazini, Leoni, J.N., Leite, S.S., de Moraes, P.A.V. International Symposium on Project Approaches in Engineering Education 8, 552-559 (2018)

31. J.W. Roberts, International Conference on Nuclear Engineering, Proceedings, ICONE, (2018)

32. A. Mottaeva, MATEC Web of Conferences 193, 01022 (2018) doi.org/10.1051/matecconf/201819301022

33. On the strategy for the information society development in the Russian Federation for 2017-2030: Decree of the President of the Russian Federation of May 9, 2017 No. 203 http://www.consultant.ru/.

34. V.G. Khalin, Chernova G.V., Management Consulting 10 (2018)

35. A digital revolution is taking place in HR departments, https://www.vedomosti.ru/

36. E.N. Rudskaya, Bezvesselnaya A.S., Potapenko D.A. The impact of robotization on the labor market: new forms of employment

37. L.A. Danchenok, A.S. Zaitseva, N.V. Komleva, Open education 23(1),34-45 (2019)

38. M.A. Menshikova, M.A. Grebennikova, Modern problems of economics and management: proceedings of the international scientific-practical conference (2019)

39. V.M. Zhurakovsky, Modernization of engineering education: Russian traditions and modern innovations: collection of the international scientific and practical conference proceedings (2017)

40. M.A. Rozhina, Gogolev R.O., Timofeeva A-M.V., Modernization of engineering education: Russian traditions and modern innovations: collection of the international scientific and practical conference proceedings (2017) 
41. A. Evmenov, E. Krolivetsky, S. Krolivetskaya, T. Sorvina, E3S Web of Conferences 164, 10036 (2020) DOI: 10.1051/e3sconf/202016410036

42. V. Krolivetskaya, E. Krolivetsky, E3S Web Conf. 135, 04032 (2019) DOI: 10.1051 / e3sconf / 201913504032

43. D. Radushinsky, Fedosina A., T. Pokrovskaya, E3S Web of Conferences 210, 13038 (2020) DOI: $10.1051 / \mathrm{e} 3$ sconf $/ 202021013038$

44. D. Radushinsky, Radushinskaya A., Radikov I., et al., MATEC Web of Conferences 170, 01043 (2018) DOI: 10.1051/matecconf/201817001043.

45. G.S. Armashova-Telnik, Nikitina N.M., Romanova I.V., Proceedings of the Voronezh State University of Engineering Technologies 82(4), 395-403 (2020)

46. G.S. Armashova, Kanavcev M.V., Proceedings of the Voronezh State University of Engineering Technologies 81(4), 205-210 (2019) 